\title{
圈 \\ The Impact of Ownership Structure and Dividends on Firm's Performance: Evidence from Manufacturing Companies Listed on the Amman Stock Exchange
}

\author{
Mo’taz Amin Al Sa'eed ${ }^{1}$
}

\begin{abstract}
This study aims to present empirical analysis from Amman Stock Exchange (ASE) to address the impact of ownership structure and dividends on the performance of Jordanian Manufacturing Companies. To test the study hypotheses and to achieve its objectives, the annual financial reports of all manufacturing companies and other related data during the period 2011 to 2015 were analyzed. Thus, Ownership structure and dividends are presented as independent variables, while the firm's performance is articulated as the dependent variable. It applies four diverse acceptable measurement tools as a proxy for the firm's performance (dependent variable); (Tobin's Q), (ROA), (ROE), and (NPM). The study found that the main variables (MO, CO, and DYLD) and the control variables (EPS and Total Assets) are good predictors of firm's performance. Also; the study found that (ROA) and (Tobin's Q) are the most representative indicators as proxies of the firm's performance. The study recommends considering another control variable to enhance predicting the firm's performance such as governance mechanisms, board structure, management competence, motivation-based payment structure, capital structure and external and internal auditing.
\end{abstract}

JEL Classification: G32, G35, M41, L60.

Keywords: Concentrated and management ownership, dividends, firm's performance, Tobin's Q, ROA, ROE, NPM.

\footnotetext{
${ }^{1}$ Associate Professor - Accounting and Accounting Information Systems Department.

Al Balqa’ Applied University, Amman -Jordan. Email: motazalsaid@yahoo.com - motaz_saeed@,bau.edu.jo
}

This work has been carried out during sabbatical leave granted to the author (Dr. Mo'taz Amin Abdelhameed Al-Sa'eed) from Al Balqa' Applied University (BAU) during the academic year 2016/2017 -2nd semester and 2017/2018 1st semester. 


\section{Introduction}

For many years, the relationship between ownership structure, dividends structure, and firm performance are considered key areas of study in the field of Corporate Governance, to ensure the best performance and diminish agency costs, ownership structure is one of the main governance tools along with other factors such as board, leverage, motivation-based payment, dividends, and assurance services. Many studies revealed the relationship between ownership structure and firm performance such as Morck et al., (2000). While previous studies have found that there is a need to provide more evidence on the linkage between a firm's performance and dividends. The payout decision is materially considered by both shareholders and executives (Baker \& Powell, 1999; Ajanthan, 2013; Azeez \& Latifat, 2015). Dividends payout is usually emerged from the firm's earnings, performance and cash flow (Ahmed \& Javid, 2009). Dividends policy is important because it determines the payout, retained earnings ratio, and performance. Firm performance, in this instance, can be presented as to how better a firm maximizes its investor's wealth and the generating earnings from the investments by investors. (Baker \& Powell, 2001).

Some previous studies have different proposals about the positive relationship between payouts and future share prices, such as (Dhanani, 2005), while others; such as (Farsio et al., 2004) argue that dividends do not have an illustrative impact to forecast future performance. Few studies have addressed the impact of ownership structure and dividends payout policies collectively on firm's performance in the Middle East countries. Our study may be considered one of the entrepreneur studies which address Jordan as a developing country.

This study aims to provide empirical evidence from Amman Stock Exchange (ASE) to address the impact of ownership structure and dividends on firm's performance of Jordanian Manufacturing firms listed on (ASE). A sample of listed firms over the recent six-year period (2010-2015) was selected. Data was processed from the financial statements of the sample. Many works of literature have measured the firm's performance in different manners; Khamees, et al. (2014) only implemented (ROA) and (Tobin's Q), While (Murekefu and Ouma (2012) run (NPAT) Margin, Amidu (2007) used (ROA), (ROE), and (Tobin's Q) as a robustness check. Shu-Ching \& Wenching (2006), measured the performance by running (ROA), (EPS), (NPM) and (ROE). Nadia (2004) used the accounting measurement (ROA). Holderness et al., (1999). Himmelberg et al. (1999), Cho (1998), Loderer and Martin (1997), Hermalin and Weisbach (1991), McConnell and Servaes (1990), all used (Tobin's Q) as a proxy for performance measurement.

In order to diagnose and address the differences in results when running each measurement of the above measures; our study is going to use (Tobin's Q) in addition to other relevant accounting measures (ROA, ROE, and NPM) as interpreters of firm's performance.

The outcomes of this study are anticipated to be valuable to many involved parties, such as; investors, finance directors, and academic sides. When making an investment decision and portfolio management, developing a dividends policy, and adds more to the existing accounting and financial literacy. The rest of this paper is organized as follows: Section two provides problem definition, Section three provides literature reviews and hypotheses development, 
Al Sa'eed | The Impact of Ownership Structure and Dividends on Firm's Performance

section four presents methodology used in data collection and analysis; the fifth one discusses the findings, while section six presents a brief conclusion.

\section{Problem Definition}

Ownership structure, dividends policies, and firm's performance are essential fields of research in the area of corporate governance and agency theory.

A Jordanian study by Jaafar and El-Shawwa (2009) found a relationship between performance and ownership concentration, board size, and multiple directorships performance respectively. Another study was conducted in Bahrain by Khamees et al., (2015) used (ROA) and (Tobin's Q) revealed that dividends and institutional ownership positively affect performance. Also; Morck et al. (2000) supported that the firm's value rises when management ownership increases. Other studies found that ownership structure is insignificant in interpreting firm's performance (Domsetz and Villalonga 2001). There are not any clear pieces of evidence provided by the association between Ownership structure, dividends payout and firm's performance in Jordan; while there are many previous kinds of literature from developed economies have focused on the association between those factors; therefore, this study is looking for filling this gap in the literature by empirically examining the impact of Ownership structure and Dividend Payout on the Firm's performance in Jordan.

Thus; this study will use the following four performance measures; (Tobin's Q, ROA, ROE, and NPM) as interpreters of the performance of manufacturing companies listed on ASE.

The study may provide answers to the following two main questions:

1. Is there any impact of ownership structure on firm's performance?

2. Is there any impact of dividends on firm's performance?

3. Which performance measure is the most representative as a proxy for the firm's performance?

Also; the study aims to provide empirical evidence on the following question:

4. Is there any impact of control variables on the firm's performance?

\section{Literature Review and Hypotheses Development}

\section{Ownership structure and Firm's Performance}

The relationship between a firm's performance and ownership structure and measured by ownership concentration and management ownership has been studied by many types of research. McConnell and Servaes (1990) found a significant positive relationship among Tobin's $\mathrm{Q}$ as a measure of a firm's performance and institutional investors.

Morck et al. (1988), Thomsen and Pedersen (2000), Chen et al. (2005), Vein, Krivogorsky (2006), Cornett et al. (2008) found a significant relationship between ownership structure and 
firm performance. Jaafar \& El-Shawwa (2009) found that ownership concentration has a positive relationship with performance; While other studies found the opposite (Cho, 1998), (Reyana and Valdes, 2012), and (Wahla et al., 2012) revealed a negative relation. Other studies also found that increased management, concentrated ownership, and payouts regularly increase firm value (Morck et al., 2000; Sarac, 2002; Arnott \& Asness, 2003; Berger, 2003;Sulong \& Nor, 2008). A study conducted in Bahrain by Khamees et al., (2015) used (ROA) and (Tobin's Q); revealed that Institutional ownership had a positive effect on performance when using T'Q while it had a negative insignificance effect when using ROA.

Based on the presented literature review, we could develop the following hypothesis in order to report on the Impact of Ownership Structure on Firm's Performance, by applying the four suggested measures of Firm's Performance (Tobin's Q, ROA, ROE, and NPM).

H01: There is no any impact of ownership structure on the performance of Jordanian manufacturing companies listed on the Amman Stock Exchange.

\section{Dividends Payout and Firm Performance}

Many studies tried to address issues concerning the dividend payout policy and their proposed impact on a firm's performance. Studies conducted by Miller and Rock (1985) argued that dividend policy plays a major role in predicting the firm's value which enhances shareholders wealth. Other studies provided that dividend payout has a significant impact on a firm's performance (Zeckhauser \& Pound 1990; Baker et al., 2001; Sulong \& Nor, 2008; Uwalomwa et al., 2012; Murekefu \& Ouma, 2013; Ajanthan ,2013), another study conducted in Bahrain by Khamees, et al, (2015) used two different measurements of performance (ROA) and (Tobin's Q) revealed that dividends have a constructive impact on performance when using both measurements of performance. However; Gill and Tibrewala (2010) found a negative relationship. Kapoor et al. (2010) and Fersio, et al. (2004) found an insignificant association between dividends and performance.

Based on the presented literature, we could develop the following hypothesis in order to report on the Impact of Dividends on Firm's Performance, by applying the four suggested measures of Firm's Performance (Tobin's Q, ROA, ROE, and NPM).

H02: There is no any impact of Dividends on the performance of Jordanian manufacturing companies listed on the Amman Stock Exchange.

\section{Data gathering and research methodology}

This study selects all 67 manufacturing companies listed on ASE. In order to test the study hypotheses and to achieve its objectives, the annual financial reports and other related data of the study sample during the period 2011 to 2015 were analyzed. To diagnose and address the differences in results when using each one of the agreed measures and to assess the relevance of each one to justify variant results found by previous studies; our study used Tobin's Q along with other relevant accounting measures (ROA, ROE, and NPM) as interpreters of firm's 
performance. We run the regression analysis, ANOVA and Coefficient Analysis to provide new empirical evidence on whether and in what way choice of measure of ownership structure (MO and CO) and Dividends (DYLD) might impact the firm's performance. Also; four control variables were added to the model (DEBT RATIO, ASSETS TURNOVER, TOTAL ASSETS and EPS). The three main independent variables (MO, CO, and DYLD) were added, one by one, to the four different sets of control variables, and their behavior is then compared to the regression coefficient analysis.

\section{The Study variables}

The study aims to figure out the impact of ownership structure and dividends on firm's performance Thus, Ownership structure and dividends are reflected as independent variables, while the firm's performance is the dependent variable. The study applies four different acceptable measurement tools (Tobin's Q, ROA, ROE, and NPM) as interpreters of a firm's performance.

\section{Dependent Variables}

\section{Firm's Performance}

Firm's performance is the dependent variable which has been measured in other empirical studies by using various accounting measures. (Sher \& Yang, 2005), and (Shu-Ching \& Wenching, 2006) all used (ROA, ROE, EPS, ROS, and NPM), while; Tobin's $Q$ was used by (Morck et al., 1988, 2000), (McConnell and Servaes, 1990) and (Khamis et al., 2015) as an interpreter of firm's performance. Firm's performance is expressed by the following four interpreters (Tobin's Q, ROA, ROE, and NPM).

\section{$\underline{\text { Tobin's Q }}$}

Tobin's Q for individual companies is thought of like the (market value of equity and liabilities) / (book value of equity and liabilities). Obtaining the book value of equity and liabilities is generally easier than getting the market valuation due to changes in daily market valuations. Sulong and Nor (2008) reproduced the calculation of the modified version of Tobin's q ratio as a measure of a firm's performance. This measure is broadly used in many kinds of literature; such as (Mehran, 2008; Rathinasamy et al., 2000; Wolfe \& Sauaia, 2003).

The simplified form of Tobin's Q ratio is depicted as follows:

Simple $Q=($ Market Value of Equity + Total DEBT) / Book value of TOTAL ASSETS

When Tobin's Q ratio is greater than one shows that the market values the firm as being worthy (Faizah, 2006).

\section{Return on Equity (ROE)}

ROE is an accounting based measure of performance in corporate governance research. (ROE) is an important interpreter of the performance. Further; Zeitun and Tian (2007) found that ROA 
and ROE are the most significant measures used by analysts. It measures the profitability of funds invested by stockholders; this measure is formed as follows:

ROE = Annual Net Income /Stockholders' equity.

\section{$\underline{\text { Return on Assets }}$}

ROA is used to measure a firm's income in relation to all other assets. It measures the effectiveness of economic resources allocated to the business. Wu and Cui (2002) afford that there is a positive relationship between ownership concentration and firm's performance calculated by ROA.

The ROA is calculated by dividing the net income by total assets deployed in the business over the reporting period. It is presented as:

ROA = Net Income / Total Assets.

\section{Net profit After-Tax Margin - NPM}

NPM is a financial performance ratio, calculated by dividing net income after taxes by net sales. A firm's NPM is an essential measure because it indicates the amount of earned profit per dollar of sales. This ratio is presented as follows:

$N P M=N P A T / N E T$ SALES

Based on our review of performance measures, and In order to answer the third question of the study; this study developed the following hypothesis:

H03: There aren't any performance measures defined as a proxy for a firm's performance.

\section{Independent Variables}

\section{Ownership Structure}

The study used two main independent variables which are Management Ownership (MO) and Concentrated Ownership (CO). In this study; we defined Concentrated Ownership as percentage shares held by the top five shareholders. A motive for using a five percent threshold is likely to be the Jordanian disclosure requirements by the Jordan Securities Commission. Specifically, the five largest shareholders are considered to be major shareholders irrespective of their share sizes. Concentration measures are usually more effective in terms of both predicting powers of the model and the significance level of their regression coefficient. Shleifer and Vishny (1986) disputed that concentrated ownership would cut the agency cost, and later rising the firm's performance. Also; Wu and Cui (2002) provided that there is a positive relationship between concentrated ownership and firm's performance measured in term of ROA. While; Manawaduge et al. (2009) revealed that ownership concentration did not show any effect on performance. 
The study used the top five Concentrated Ownership (CR5) model as follows (Sulong and Nor 2008):

$$
C R 5=\operatorname{Top} 1 / \sum_{i=1}^{5} \gamma i
$$

Whereas Management Ownership is known as percentage shares held by managers, CEOs, etc. A lot of literature provided the shares owned by managers form the management ownership (Morck et al. 1988; Chen et al. 2003).

\section{Dividends}

Dividends were principally measured by dividends yield (dividends paid per share -to- market share price ratio). That is, $D Y L D=D P S / M P S$. The dividend yield was considered instead of the payout ratio for two reasons. Firstly, the denominator in dividends yield is share price compared to an accounting measure (net income). Secondly, to evade difficulties of negative payout ratios are caused by negative income or excessively high payout ratios resulting from income being close to zero (Schooley and Barney, 1994).

\section{Control variables}

\section{Debt Ratio and Assets Turnover}

Debt Ratio and Assets Turnover are taken as control variables. Debt Ratio (Debt) is functioned out as the ratio of total liabilities to total assets. Jensen (1986) strains the significance of debt in restrictive managerial choice over the use of free cash flow; Stulz (1988) and Bhabra (2007) propose an opposite relationship between leverage and firm's performance. Jensen and Meckling (1976) disputed that debt is an adjusting tool that eases agency problems between management and other shareholders; therefore, leverage impacts firm's performance through monitoring activities by debt holders, thus our study presented it as total debt divided by total assets to form the Debt Ratio (Debt).

Assets turnover (AT) is calculated by dividing total sales by total assets. This control variable was used by (Sulong and Nor, 2008) (Hamid Ulla et al., 2012) and (Khamees et al. 2015).

\section{$\underline{\text { Firm Size }}$}

Our study considered firm size because it is likely that big firms seem attractive to stockholders. Large firms may pay high dividends as discussed in Redding (1997). Short and Keasey (1999) found that firm size has an effect on a firm's performance, while; Bhabra (2007) reveals that firm' performance is negatively associated with firm size. Many previous studies have used total assets to represent firm size (Khamees et al., 2015) and (Hamid Ullad et al. 2012). Our study used total assets (FSIZE) as the indicator of firm size. 


\section{Earnings per Share (EPS)}

Earnings per share (EPS) ratio is calculated by dividing the income less preferred dividends by the weighted average number of outstanding common shares. This measurement is used by (Sulong and Nor, 2008), (Kumar and Sopariwala, 1992), and (Ahmed and Khababa, 1999). Khamees et al. (2015) provided that EPS has an observed noticed impact on performance, while Sulong and Nor (2008) provided a negative insignificant effect of EPS on Firm's performance using T'Q. Our study used EPS to address the conflicting results of previous studies.

The EPS = net income less preferred dividends / weighted average number of outstanding common shares.

Based on our review of control variables and the way they were deployed, this study developed the following hypothesis to answer the fourth question of the study.

H04: There is no any impact of control variables on the performance of Jordanian manufacturing companies listed on the Amman Stock Exchange.

\section{The study regression model:}

Based on the above-explained variables of the study; we are able to develop the following empirical model:

FPit (Tobin's Q) $=\alpha i t+\beta 1$ MOit $+\beta 2$ COit $+\beta 3$ DYLDit $+\beta 4$ Debt $+\beta 5$ ATit $+\beta 6$ FSIZE $+\beta 7$ Prof + eit Eq

FPit $($ ROA $)=\alpha i t+\beta 1$ MOit $+\beta 2$ COit $+\beta 3$ DYLDit $+\beta 4$ Debt $+\beta 5$ ATit $+\beta 6$ FSIZE $+\beta 7$ Prof + cit $E q$

FPit $($ ROE $)=\alpha i t+\beta 1$ MOit $+\beta 2$ COit $+\beta 3$ DYLDit $+\beta 4$ Debt $+\beta 5$ ATit $+\beta 6$ FSIZE $+\beta 7$ Prof + cit $E q$

FPit $(N P M)=\alpha i t+\beta 1$ MOit $+\beta 2$ COit $+\beta 3$ DYLDit $+\beta 4$ Debt $+\beta 5$ ATit $+\beta 6$ FSIZE $+\beta 7$ Prof + eit $E q$

Where:

FP = Firm Performance represented by Tobin's Q, ROA, ROE, and NPM.

$M O \quad=$ Managerial Ownership

$\mathrm{CO}=$ Concentrated Ownership

$D Y L D=$ DPS / MPS (Dividends per share divided to Market Price per Share

Debt $=$ Debt Ratio $=$ Total Debts $/$ Total Assets.

$A T=$ Assets Turnover

FSIZE $=$ Total assets in thousands

Prof $=$ represented by EPS. 
Al Sa'eed | The Impact of Ownership Structure and Dividends on Firm's Performance

$$
\begin{array}{ll}
\alpha & =\text { the constant term } \\
\mathrm{B} & =\text { coefficient } \\
\varepsilon & =\text { Error term and Subscript } \\
(\mathrm{i}, \mathrm{t}) & =\text { the value of the panel data variable " } \mathrm{i} \text { " in year " } \mathrm{t} \text { ". }
\end{array}
$$

\section{Empirical Analysis}

The empirical analysis consists of regression, ANOVA, and the coefficient for each variable. The package 'Statistical Package for Social Sciences' (SPSS) 18.0 Version was deployed in order to analyze the data.

\section{Multicollinearity test}

This study tested multicollinearity between independent variables; it was found that Inflation factor (VIF) value is less than 5 and above 0.1 so that there are no indicators of multicollinearity between independent variables. The test for multicollinearity was conducted before analyzing the regression model. As mentioned by Field (2000), this test is important because multicollinearity can influence the parameters of a regression model.

\section{Empirical Analysis and Discussion}

Table 1: Regression Analysis

\begin{tabular}{|l|l|l|l|l|l|l|}
\hline Dependent Variable & Independent Variable & Model & R & R Square & Adjusted R Square & St. Error \\
\hline Tobins' Q & MO & 1 & $.448^{\mathrm{a}}$ & .200 & .191 & .64707260592 \\
\hline ROA & MO & 1 & $.729^{\mathrm{a}}$ & .531 & .526 & 7.1965219547 \\
\hline ROE & MO & 1 & $.175^{\mathrm{a}}$ & .031 & .019 & 16.844465414 \\
\hline NPM & MO & 1 & $.449^{\mathrm{a}}$ & .202 & .191 & .41232555470 \\
\hline Tobins' Q & CO & 1 & $.507^{\mathrm{a}}$ & .257 & .248 & .62265940783 \\
\hline ROA & CO & 1 & $.770^{\mathrm{a}}$ & .592 & .587 & 5.8113902894 \\
\hline ROE & CO & 1 & $.183^{\mathrm{a}}$ & .034 & .021 & 17.269027239 \\
\hline NPM & CO & 1 & $.470^{\mathrm{a}}$ & .221 & .210 & .35389045225 \\
\hline Tobins' Q & DYLD & $.442^{\mathrm{a}}$ & .196 & .186 & .64826008931 \\
\hline ROA & 1 & $.733^{\mathrm{a}}$ & .537 & .531 & 7.1676083852 \\
\hline ROE & DYLD & 1 & $.178^{\mathrm{a}}$ & .032 & .020 & 16.877145693 \\
\hline NPM & DYLD & 1 & $.443^{\mathrm{a}}$ & .196 & .185 & .41499735022 \\
\hline
\end{tabular}

Table 2: ANOVA Analysis

\begin{tabular}{|l|l|l|l|l|}
\hline Dependent Variable & Independent variable & Mean Square & F & Sig. \\
\hline Tobins' Q & MO & 8.544 & 20.405 & $.000^{\mathrm{b}}$ \\
\hline ROA & MO & 4781.010 & 92.315 & $.000^{\mathrm{b}}$ \\
\hline ROE & MO & 730.056 & 2.573 & $.026^{\mathrm{b}}$ \\
\hline NPM & MO & 3.200 & 18.824 & $.000^{\mathrm{b}}$ \\
\hline Tobins' Q & CO & 10.372 & 26.751 & $.000^{\mathrm{b}}$ \\
\hline ROA & CO & 3785.342 & 112.084 & $.000^{\mathrm{b}}$ \\
\hline ROE & CO & 801.246 & 2.687 & $.021^{\mathrm{b}}$ \\
\hline NPM & CO & 2.552 & 20.375 & $.000^{\mathrm{b}}$ \\
\hline Tobins' Q & DYLD & 8.275 & 19.690 & $.000^{\mathrm{b}}$ \\
\hline ROA & DYLD & 4828.700 & 93.990 & $.000^{\mathrm{b}}$ \\
\hline ROE & DYLD & 754.025 & 2.647 & $.023^{\mathrm{b}}$ \\
\hline NPM & DYLD & 3.104 & 18.021 & $.000^{\mathrm{b}}$ \\
\hline
\end{tabular}


According to above tables (1 and 2); this study found high consistency between regression and ANOVA analysis, it is found that MO, CO, and DYLD have the highest correlation with the firm's performance which measured by ROA when comparing with other among other independent variables. What the results mean is that $53.1 \%, 59.2 \%$ and $53.7 \%$ respectively; of the variance (R-Square) in the extent of dependent variable has been significantly explained by the independent variables (MO, CO, and DYLD). Furthermore; F- Test showed that MO, CO, and DYLD have the highest significant impact on firm's performance measured in terms of ROA $(92.315 \%, 112.084 \%$, and $93.990 \%)$ respectively.

This result could be explained of that when the ownership of outstanding shares is concentrated by management, and top shareholders will motivate and drive them to concentrate on utilizing assets as a measure of good financial performance which will positively increase their compensation, dividends, and returns as they are jointly accountable to the board and other minor investors for utilizing assets. In addition to that; concentrated ownership by management and top shareholders will lead them to feel that the firm is their own investment by which they will work together to increase (ROA) as a financial measure of firm's performance by directing and affecting the operational and financial policies and decisions to ensure the highest level of return on invested assets in the firm.

On the other hand; DYLD plays a significant positive role on the firm's performance measured by the return on assets of that DYLD encourages both management and top shareholder to utilize the usage of invested assets to ensure they will get more payout ratio out of achieved return, in other words; DYLD motivates management and top shareholders to manage and operate the invested assets in a productive manner to get more cash proceeds for their investments in the firm. Also; Shareholder's wealth is maximized through effective investment strategies, financed by an optimal capital structure. Furthermore; this study found that MO, CO, and DYLD have a significant positive correlation with firm's performance which measured by Tobin's Q and NPM. While the MO, CO and DYLD also have an insignificant positive correlation with ROE as a proxy of firm's performance ( $\mathrm{R}$ Square $\mathrm{MO}=3.1 \%, \mathrm{CO}=3.4 \%$ and DYLD $=3.2 \%$ ) and (F-Test $\mathrm{MO}=2.573 \%, \mathrm{CO}=2.687 \%$ and $\mathrm{DYLD}=2.647 \%$ ) respectively. So, the correlation of $\mathrm{MO}$, CO, and DYLD with firm's performance measures (ROA, Tobin's Q and NPM) is still significant positive, but explicitly more than the significant correlation with ROE.

A company's after-tax profit margin (NPM) is important because it tells investors the percentage of money a company actually earns per dollar of sales. These results are in line with $\mathrm{Xu}$ and Wang (1999), Ajanthan, (2013) and Sulong and Nor (2008).

Also; Thomsen and Pedersen (2000), Chen et al. (2005), Vein Krivogorsky (2006), Cornett et al. (2008) and Jaafar \& El-Shawwa (2009) found a positive relation between ownership concentration and firm's performance. On the contrast; the study results disagree with the study of Severin (2001). Also; the result of this study is lined with Khamees et al., (2015).

The results of this study are lined with Uwalomwa et al., (2012), Murekefu and Ouma, (2013), Ajanthan, (2013), and Priya and Nimalathasan, (2013), all of these studies revealed that dividend payout has significant impact on a firm's performance, also; when managers have a significant ownership (MO) they will influence the dividends policy in order to give a good indicator of a 
Al Sa'eed | The Impact of Ownership Structure and Dividends on Firm's Performance

firm's performance especially when this policy meets the top shareholders expectations, this result is in line with Zeckhauser and Pound's (1990) argument as they mentioned that dividend policy could be used as a signal for the firm's performance. However; our results disagree with Gill and Tibrewala, (2010).

In conclusion; this study found that (MO. CO and DYLD) have the highest positive correlation with and significant positive impact on firm's performance when measured in terms of ROA, while the least positive correlation with firm's performance was ROE. In addition to that; MO, CO, and DYLD have also a positive significant correlation and impact on firm's performance when measured in terms of Tobin's Q and NPM.

Table 3: Coefficient Analysis - Management Ownership (MO)

\begin{tabular}{|c|c|c|c|c|c|c|}
\hline \multicolumn{2}{|l|}{ Model } & \multicolumn{2}{|c|}{$\begin{array}{l}\text { Unstandardized } \\
\text { Coefficients }\end{array}$} & \multirow{2}{*}{$\begin{array}{l}\text { Standardized } \\
\text { Coefficients } \\
\text { Beta }\end{array}$} & \multirow[t]{2}{*}{$\mathrm{t}$} & \multirow[t]{2}{*}{ Sig. } \\
\hline & & $\mathrm{B}$ & Std. Error & & & \\
\hline \multirow{6}{*}{ Tobins' Q } & (Constant) & .948 & .077 & & 12.351 & .000 \\
\hline & MO & -2.149 & .809 & -.118 & -2.658 & .008 \\
\hline & DEBT RATIO & .006 & .153 & .002 & .037 & .971 \\
\hline & ASSETS TURNOVER & -.495 & .089 & -.254 & -5.537 & .000 \\
\hline & TOTAL ASSETS( SIZE) & $-2.049 \mathrm{E}-010$ & .000 & -.051 & -.824 & .410 \\
\hline & EPS( PROF) & .783 & .120 & .430 & 6.537 & .000 \\
\hline \multirow{6}{*}{ ROA } & (Constant) & -2.196 & .854 & & -2.573 & .010 \\
\hline & MO & 21.537 & 8.992 & .082 & 2.395 & .017 \\
\hline & DEBT RATIO & -1.152 & 1.697 & -.024 & -.679 & .497 \\
\hline & ASSETS TURNOVER & 5.440 & .994 & .193 & 5.472 & .000 \\
\hline & TOTAL ASSETS( SIZE) & $-2.061 \mathrm{E}-008$ & .000 & -.355 & -7.460 & .000 \\
\hline & EPS( PROF) & 22.274 & 1.332 & .843 & 16.725 & .000 \\
\hline \multirow{6}{*}{ ROE } & (Constant) & 3.537 & 1.998 & & 1.770 & .077 \\
\hline & $\mathrm{MO}$ & 6.869 & 21.048 & .016 & .326 & .744 \\
\hline & DEBT RATIO & -8.484 & 3.972 & -.111 & -2.136 & .033 \\
\hline & ASSETS TURNOVER & -2.692 & 2.327 & -.059 & -1.157 & .248 \\
\hline & TOTAL ASSETS( SIZE) & $-7.833 \mathrm{E}-009$ & .000 & -.083 & -1.211 & .226 \\
\hline & EPS( PROF) & 5.819 & 3.117 & .135 & 1.867 & .063 \\
\hline \multirow{6}{*}{ NPM } & (Constant) & -.136 & .059 & & -2.313 & .021 \\
\hline & MO & .918 & .519 & .082 & 1.769 & .078 \\
\hline & DEBT RATIO & -.346 & .102 & -.166 & -3.392 & .001 \\
\hline & ASSETS TURNOVER & .279 & .064 & .208 & 4.363 & .000 \\
\hline & TOTAL ASSETS( SIZE) & $-2.680 \mathrm{E}-010$ & .000 & -.110 & -1.672 & .095 \\
\hline & EPS( PROF) & .372 & .077 & .331 & 4.803 & .000 \\
\hline
\end{tabular}


AABFJ | Volume 12, no. 3, 2018

Table 4: Coefficient Analysis - Concentrated Ownership (CO)

\begin{tabular}{|c|c|c|c|c|c|c|}
\hline \multicolumn{2}{|l|}{ Model } & \multirow{2}{*}{\multicolumn{2}{|c|}{ Unstandardized Coefficients }} & \multirow{2}{*}{\begin{tabular}{|l|} 
Standardized \\
Coefficients \\
Beta \\
\end{tabular}} & \multirow{3}{*}{\begin{tabular}{|l} 
t \\
3.400
\end{tabular}} & \multirow{3}{*}{$\begin{array}{l}\text { Sig. } \\
.001\end{array}$} \\
\hline & & & & & & \\
\hline \multirow{6}{*}{ Tobins' Q } & (Constant) & $\begin{array}{l}\mathrm{B} \\
.407\end{array}$ & \begin{tabular}{|l|} 
Std. Error \\
.120
\end{tabular} & & & \\
\hline & DEBT RATIO & -.108 & .152 & -.033 & -.713 & .477 \\
\hline & ASSETS TURNOVER & -.486 & .090 & -.245 & -5.392 & .000 \\
\hline & TOTAL ASSETS( SIZE) & $-4.483 \mathrm{E}-010$ & .000 & -.115 & -1.836 & .067 \\
\hline & EPS( PROF) & .822 & .117 & .459 & 7.055 & .000 \\
\hline & $\mathrm{CO}$ & .008 & .002 & .252 & 5.561 & .000 \\
\hline \multirow{6}{*}{ ROA } & (Constant) & -1.640 & 1.119 & & -1.466 & .143 \\
\hline & DEBT RATIO & -1.190 & 1.417 & -.029 & -.840 & .401 \\
\hline & ASSETS TURNOVER & 4.838 & .842 & .194 & 5.747 & .000 \\
\hline & TOTAL ASSETS( SIZE) & $-1.860 \mathrm{E}-008$ & .000 & -.379 & -8.163 & .000 \\
\hline & EPS( PROF) & 20.358 & 1.088 & .903 & 18.718 & .000 \\
\hline & $\mathrm{CO}$ & .007 & .014 & .015 & .462 & .645 \\
\hline \multirow{6}{*}{ ROE } & (Constant) & 6.121 & 3.324 & & 1.841 & .066 \\
\hline & DEBT RATIO & -8.717 & 4.209 & -.111 & -2.071 & .039 \\
\hline & ASSETS TURNOVER & -2.681 & 2.502 & -.056 & -1.072 & .285 \\
\hline & TOTAL ASSETS( SIZE) & $-7.056 \mathrm{E}-009$ & .000 & -.075 & -1.042 & .298 \\
\hline & EPS( PROF) & 5.849 & 3.232 & .134 & 1.810 & .071 \\
\hline & $\mathrm{CO}$ & -.038 & .042 & -.046 & -.899 & .369 \\
\hline \multirow{6}{*}{ NPM } & (Constant) & -.185 & .074 & & -2.482 & .014 \\
\hline & DEBT RATIO & -.430 & .090 & -.236 & -4.781 & .000 \\
\hline & ASSETS TURNOVER & .221 & .056 & .187 & 3.918 & .000 \\
\hline & TOTAL ASSETS( SIZE) & $-3.075 \mathrm{E}-010$ & .000 & -.147 & -2.185 & .030 \\
\hline & EPS( PROF) & .330 & .067 & .342 & 4.934 & .000 \\
\hline & $\mathrm{CO}$ & .002 & .001 & .121 & 2.497 & .013 \\
\hline
\end{tabular}

Table 5: Coefficients Analysis - Dividends Payout (DYLD)

\begin{tabular}{|c|c|c|c|c|c|c|}
\hline \multicolumn{2}{|l|}{ Model } & \multicolumn{2}{|c|}{ Unstandardized Coefficients } & \multirow{2}{*}{$\begin{array}{l}\text { Standardized } \\
\text { Coefficients } \\
\text { Beta }\end{array}$} & \multirow[t]{2}{*}{$\mathrm{t}$} & \multirow[t]{2}{*}{ Sig. } \\
\hline & & $\mathrm{B}$ & Std. Error & & & \\
\hline \multirow{6}{*}{ Tobins' Q } & (Constant) & .975 & .080 & & 12.144 & .000 \\
\hline & DEBT RATIO & -.071 & .159 & -.022 & -.449 & .654 \\
\hline & ASSETS TURNOVER & -.467 & .091 & -.241 & -5.107 & .000 \\
\hline & TOTAL ASSETS( SIZE) & $-2.910 \mathrm{E}-010$ & .000 & -.073 & -1.146 & .253 \\
\hline & EPS( PROF) & .867 & .126 & .478 & 6.883 & .000 \\
\hline & DYLD & -2.519 & 1.195 & -.109 & -2.108 & .036 \\
\hline \multirow{6}{*}{ ROA } & (Constant) & -2.765 & .887 & & -3.116 & .002 \\
\hline & DEBT RATIO & .061 & 1.753 & .001 & .035 & .972 \\
\hline & ASSETS TURNOVER & 4.879 & 1.011 & .173 & 4.827 & .000 \\
\hline & TOTAL ASSETS( SIZE) & $-1.892 \mathrm{E}-008$ & .000 & -.326 & -6.739 & .000 \\
\hline & EPS( PROF) & 20.750 & 1.393 & .785 & 14.895 & .000 \\
\hline & DYLD & 43.631 & 13.214 & .129 & 3.302 & .001 \\
\hline
\end{tabular}


Al Sa'eed | The Impact of Ownership Structure and Dividends on Firm's Performance

\begin{tabular}{|l|l|l|l|l|l|l|}
\hline \multirow{5}{*}{} & (Constant) & 4.164 & 2.089 & & 1.993 & .047 \\
\cline { 2 - 7 } & DEBT RATIO & -9.379 & 4.128 & -.122 & -2.272 & .024 \\
\cline { 2 - 7 } & ASSETS TURNOVER & -2.306 & 2.380 & -.050 & -.969 & .333 \\
\cline { 2 - 7 } & TOTAL ASSETS( SIZE) & $-8.846 \mathrm{E}-009$ & .000 & -.094 & -1.338 & .182 \\
\cline { 2 - 7 } & EPS( PROF) & 6.511 & 3.280 & .151 & 1.985 & .048 \\
\cline { 2 - 7 } & DYLD & -22.581 & 31.114 & -.041 & -.726 & .468 \\
\hline \multirow{5}{*}{ NPM } & (Constant) & -.120 & .059 & & -2.018 & .044 \\
\cline { 2 - 8 } & DEBT RATIO & -.349 & .106 & -.167 & -3.290 & .001 \\
\cline { 2 - 8 } & ASSETS TURNOVER & .267 & .067 & .199 & 3.999 & .000 \\
\cline { 2 - 8 } & TOTAL ASSETS( SIZE) & $-2.612 \mathrm{E}-010$ & .000 & -.107 & -1.590 & .113 \\
\cline { 2 - 7 } & EPS( PROF) & .355 & .082 & .315 & 4.325 & .000 \\
\cline { 2 - 6 } & DYLD & .460 & .840 & .030 & .548 & .584 \\
\hline
\end{tabular}

Also, according to the coefficient table 3; it is found that $\mathrm{t}$ _values for the independent variables (MO, CO, and DYLD) $(-2.658,5.561$ and -2.108$)$ respectively and control variables (ASSETS TURNOVER, and EPS)( -5.537 and 6.537 ) are significant at 0.05 levels, which mean there is significant effect of each of them on the firm's performance measured by Tobin's Q, while it's found that DEBT RATIO and TOTAL ASSETS have insignificant coefficient with Tobin's Q as a proxy for firm's performance (Sig, 0.971 and .410) which means that Management with significant ownership preferring a stable level of debt ratio and invested assets high level of debt and assets would decrease the ROA, ROE, and NPM when fixing other variables, also; this result can explain the insignificant coefficient with Tobin's Q when Management concentrating on constant level of debt and assets. At the end; these results are referred to that Management with concentrated ownership of outstanding shares is preferring high level of assets turnover and low level of Asset (SIZE) comparing to the total debt, which reflected by insignificant coefficient of DEBT RATIO (Sig, .497) with Tobin's Q, and significant coefficient of ASSETS TURNOVER with Tobin's Q. EPS has a significant coefficient with Tobin's Q as MO prefers high EPS which positively affects the market value of the firm (MVE). Similarly; (MO ,DYLD) and control variables (ASSETS TURNOVER, size and EPS) are significant at 0.05 levels, which mean that there is significant effect of each of them on the firm's performance measured by ROA which means that these independent variables are good predictors of firm's performance when measured by ROA, while CO does not have that significant coefficient (sig, .645) with ROA, since this ratio is related directly to the management financial performance as management ownership concentration would affect assets operating and financial policies, also; increased assets turnover means that management is utilizing the firm's assets (size) in generating sales and returns as well. Consistent with correlation and ANOVA analysis in table 1 and 2 above; it's found that (MO, CO, and DYLD) and all other control variables do not have a significant coefficient with ROE except for DEBT RATIO (.033, .039, and .024) among the three study variables (MO, CO, and DYLD) respectively; only the DEBT RATIO has a significant coefficient of firm's performance measured by ROE, increased DEBT RATIO means that the firm is utilizing the financial leverage to increase ROE.

On the other hand; it's found that t _values for $(\mathrm{CO})$ and the control variables (DEBT RATIO, ASSETS TURNOVER, TOTAL ASSETS and EPS) are significant at 0.05 levels, which mean there is a significant impact of each of them on the firm's performance measured in terms of NPM. (CO) and control variables (DEBT RATIO, ASSETS TURNOVER, TOTAL ASSETS and 
EPS) are considered good predictors of firm's performance (NPM) which means also that increased financial leverage and EPS reflected in NPM as a proxy of firm's performance. While the control variable (TOTAL ASSETS -Size) has an insignificant coefficient with firm's performance measured by NPM when inserting the independent variables (MO and DYLD) (sig, .093 and 0.113 ) respectively, this exceptional result is referring to that MO is preferring a low size of total assets and would affect inversely the ROA, ROE and DYLD as well. Our results are lined with McConnell and Servaes (1990), a study by Xu and Wang (1999) showed that the mix and concentration of stock ownership are significant in explaining the firm's performance.

As for robustness of performance of the control variables, their regression coefficients are quite consistent in terms of both sign and significance level, across the four firm's performance measures; $\mathrm{MO}$ has a significant positive relationship $(\mathrm{t}=2.395$, sig, $=0.017)$ with firm's performance measured by ROA, significant negative relationship $(\mathrm{t}=-2.658$, sig, 0.008) with firm's performance measured by Tobin's Q, while MO shows insignificant positive relationship with ROE and NPM. While CO shows a significant positive relationship $(\mathrm{t}=5.561$, sig, 0.000$)$ and $(\mathrm{t}=2.497$, sig, $\quad(0.013)$ with firm's performance measured by Tobin's $\mathrm{Q}$ and NPM respectively, this result is lined with Thomsen and Pedersen (2000) in which they found a positive relation between ownership concentration and firm performance. while it shows an insignificant positive relationship with ROA and insignificant negative relationship with ROE. Morck, et al. (1988) found no significant relationship in the linear regressions they estimate when using Tobin's Q and accounting profit rate as alternative measures of performance.

DYLD shows a significant negative relationship $(\mathrm{t}=-2.108$, sig, .036) with Tobin's $\mathrm{Q}$, a significant positive relationship $(\mathrm{t}=3.302$, sig, 0.001) with ROA, and insignificant negative and insignificant positive relationship with ROE and NPM respectively. Our results are in line with those of Uwalomwa et al., (2012), Murekefu and Ouma, (2013), Ajanthan, (2013), Priya and Nimalathasan, (2013) and Khamees et al., (2015).

The major findings of the study are: First, MO and DYLD have a significant positive impact on firm's performance when deploying ROA as a proxy of firm's performance, and have a significant negative impact on firm's performance when using Tobin's Q. CO reported a significant positive impact on a firm's performance when deploying Tobin's Q and NPM. Second; MO and DYLD collectively have an insignificant positive impact on firm's performance when deploying NPM. Also; MO reported an insignificant positive impact on firm's performance when deploying ROE as a proxy of a firm's performance, while CO reported an insignificant positive impact on firm's performance when employing ROA.

Finally, CO and DYLD reported an insignificant negative impact on firm's performance when deploying ROE as a proxy of firm's performance, which means that NPM and ROE indicators are less representative as proxies of firm's performance at all, while; ROA indicator is more representative as a proxy of a firm's performance through this analysis.

Additionally, the study found that the control variable EPS has a significant positive impact on a firm's performance when deploying ROA, Tobin's Q and NPM as proxies of the firm's performance. The control variable Assets turnover reported a significant positive impact on a 
firm's performance when deploying ROA and NPM. Finally; the control variable Debt ratio reported a significant positive impact on a firm's performance when deploying ROA.

On the other hand; the control variable Total Assets reported a significant negative impact on firm's performance when deploying ROA, ROE, and NPM, while the control variable Debt ratio reported a significant negative impact on firm's performance when deploying ROE and NP. However; the control variable Assets turnover showed a significant negative impact on a firm's performance when using Tobin's Q. Table 6 summarizes the study results.

Table 6: Summary of study results

\begin{tabular}{|l|l|l|l|l|l|}
\hline $\begin{array}{l}\text { Deployed } \\
\text { Measure of } \\
\text { firm's } \\
\text { performance }\end{array}$ & $\begin{array}{l}\text { Independent } \\
\text { variable } \\
\text { (CO, MO, } \\
\text { and DYLD })\end{array}$ & $\begin{array}{l}\text { Control variable } \\
\text { (DEBT RATIO, } \\
\text { ASSETS } \\
\text { TURNOVER, } \\
\text { TOTAL } \\
\text { ASSETS and } \\
\text { EPS) }\end{array}$ & $\begin{array}{l}\text { Impact on the } \\
\text { Dependent variable } \\
\text { firm's } \\
\text { performance) }\end{array}$ & $\begin{array}{l}\text { The most } \\
\text { Representative } \\
\text { Measure as a } \\
\text { proxy of a } \\
\text { firm's } \\
\text { performance }\end{array}$ & $\begin{array}{l}\text { Hypotheses: Reject } \\
\text { /Accept }\end{array}$ \\
\hline ROA & MO, DYLD & & Significant positive & ROA & H01, H02, and H03: Reject \\
\hline $\begin{array}{l}\text { Tobin's Q } \\
\text { Nobin's Q, }\end{array}$ & MO, DYLD & Significant negative & Tobin's Q & H01, H02, and H03: Reject \\
\hline $\begin{array}{l}\text { ROA, Tobin's } \\
\text { Q, and NPM }\end{array}$ & & EPS & Significant positive & Tobin's Q & H01, H02, and H03: Reject \\
\hline ROA, NPM & Assets Turnover & Significant positive & ROA & H04 and H03: Reject \\
\hline ROA & Debt Ratio & Significant positive & ROA & H04 and H03: Reject \\
\hline $\begin{array}{l}\text { ROA, ROE, } \\
\text { NPM }\end{array}$ & & Total Assets & Significant negative & ROA & H04 and H03: Reject \\
\hline ROE, NPM & Debt Ratio & Significant negative & Not & H04 and H03: Reject \\
\hline \begin{tabular}{l} 
Tobin's Q \\
\hline
\end{tabular} & Assets turnover & Significant negative & Tobin's Q & H04 and H03: Reject \\
\hline
\end{tabular}

\section{Conclusion}

This study aimed to provide empirical evidence from Amman Stock Exchange (ASE) to address the impact of ownership structure and dividends on firm's performance of Jordanian Manufacturing Companies listed on ASE. A sample of firms over the recent six-year period (2010-2015) was selected. The data was derived from the annual financial reports of listed firms. To diagnose and address the differences in results when using each one of the agreed measures and to assess the relevance of each one to justify variant results found by previous studies; our study used Tobin's Q along with other relevant accounting measures (ROA, ROE, and NPM) as interpreters of firm's performance. We run the regression analysis, ANOVA and Coefficient Analysis to provide new empirical evidence on whether and in what way choice of measure of ownership structure (MO and $\mathrm{CO}$ ) and Dividends (DYLD) might impact the firm's performance. Also; four control variables were added to the model (DEBT RATIO, ASSETS TURNOVER, TOTAL ASSETS and EPS). The three main independent variables (MO, CO, and DYLD) were 
added, one by one, to the four different sets of control variables, and their behavior is then compared to the regression coefficient analysis.

In conclusion; our study provided an empirical evidence and rejected the null hypotheses and accepted the alternative ones; which means that ownership structure and dividends impact the firm's performance of the selected sample, the study variables (MO, CO, and DYLD) are significant predictors of firm's performance in most cases, and the control variables (EPS and Total Assets) are also significant predictors of firm's performance, while (Assets Turnover and Debt Ratio) are moderate predictors of firm's performance. In addition to that, the study found that (ROA) and (Tobin's Q) are the most representative indicators as proxies of the firm's performance, while NPM is still moderate. The study concludes that the study variables were well selected and seemed to be good predictors of firm's performance so that all of them have an impact on firm' performance.

At the end; the study recommends considering those variables for any future research, more so; another control variable could be promoted to better predicting the firm's performance such as governance mechanisms, board structure, management competence, motivation-based payment structure, capital structure and external and internal auditing.

\section{References}

Ajanthan. A.(2013)."The Relationship between Dividend Payout and Firm Profitability: A Study of Listed Hotels and Restaurant Companies in Sri Lanka "International Journal of Scientific and Research Publications. 3(6):1-6.

Ahmed, A.M., \& Khababa, N. (1999). "Performance of Banking Sector in Saudi Arabia". Journal of Financial Management \& Analysis, 12(2), 30

Amidu, M. (2007). "How does Dividend Policy Affect Performance of the firm on Ghana Stock Exchange?" Investment Management and Financial Innovations, 4(2):103-112.

Arnott, R.D. \& Asness, C.S.(2003)."Surprise! Higher dividends= higher earnings growth", Financial Analysts Journal.70-87. https://doi.org/10.2469/faj.v59.n1.2504

Azeez.A and Latifat. M. (2015). "Relationship between dividend payout and firm's performance: evaluation of dividend policy of Oando PLC". International Journal of Contemporary Applied Sciences. . 2( 6). June 2015

Baker, H. K., Veit, E. T., \& Powell, G. E. (2001). "Factors influencing dividend policy decisions of Nasdaq firms. The Financial Review, 36(3), 19-37.

Berger, A. (2003). " Capital Structure and Firm Performance: A New Approach to Testing Agency Theory and an Application to the Banking Industry". Working Paper, University of South Carolinahttp://papers.ssrn.com.

Bhabra. G. S.( 2007). "Insider ownership and firm value in New Zealand". Journal of Multinational Financial Management, 2007, vol. 17, issue 2, 142-154

https://doi.org/10.1016/j.mulfin.2006.08.001 
Al Sa'eed | The Impact of Ownership Structure and Dividends on Firm's Performance

Chen, Z., Cheung, Y.-L., Stouraitis, A., Wong, A.W.S., (2005). “Ownership concentration, firm performance, and dividend policy in Hong Kong”. Pacific-Basin Finance Journal, 13(4). https://doi.org/10.1016/i.pacfin.2004.12.001

Cho, M. H. (1998). Ownership structure, investment, and the corporate value: an empirical analysis. Journal of Financial Economics, 47(1), 103-121. http://dx.doi.org/10.1016/S0304-405X(97)00039-1

Dhanani, A. (2005). "Corporate dividend policy: The views of British financial managers". Journal of Business Finance \& Accounting, 37(7) \& (8), 1625 - 1672.

Faizah, M. S. (2006). "Effects of Corporate Ownership Structure on Performance and Capital Structure of the Non-Financial Firms Listed on the Main Board of the KLSE". Unpublished Doctor of Business Administration (DBA) Dissertation, Universiti Kebangsaan Malaysia.

Gill, B.\&Tibrewala (2010). "Stock market liquidity and firm dividend policy" The Open Business Journal. 1(3): 8-14 https://doi.org/10.2174/1874915101003010008

HaroldDemsetz.H and Villalonga. B.( 2001).” Ownership structure and corporate performance”. Journal of Corporate Finance.7(3), (2001).

Hamid Ullah, Fida. A, and Khan. S (2012).” The Impact of Ownership Structure on Dividend Policy Evidence from Emerging Markets KSE-100 Index Pakistan". International Journal of Business and Social Science .3(9), May 2012.

Hermalin, B. and Weisbach, M. (1991). "The Effects of Board Composition and Direct Incentives on Firm Performance”. Financial Management, 20(4), 101-112.

https://doi.org/10.2307/3665716

Hillman, A., Zardkoohi, A. and Bierman, L. (1999). " Corporate political strategies and firm performance: Indications of firm-specific benefits from personal service in the US government". Strategic Management Journal, 20: 67-82.

https://doi.org/10.1002/(SICI)1097-0266(199901)20:1<67::AID-SMJ22>3.0.CO;2-T

Himmelberg, C P, Hubbard, R G \& Palia, D (1999). "Understanding the Determinants of Managerial Ownership and the Link Between Ownership and Performance". Journal of Financial Economics,53, 353-384. https://doi.org/10.1016/S0304-405X(99)00025-2

Holderness, C.G., Kroszner, R.S., Sheehan, D.P. (1999). "Were the good old days that good? Changes in managerial stock ownership since the Great Depression". Journal of Finance 54, 435-470. https://doi.org/10.1111/0022-1082.00114

Jaafar, A. and El Shawa, M. (2009). "Ownership Concentration, Board Characteristics and Performance: Evidence from Jordan. SSRN: http://ssrn.com/abstract=1392727

Jensen, M. (1986). “Agency Costs of Free Cash Flow, Corporate Finance and Takeovers". American Economic Review Papers and Proceedings, 76(2): 323-329.

Jensen MC, Meckling W (1976). "Theory of the Firm: Managerial Behavior, Agency Costs, and Ownership Structure”. Journal of Finance Economics .3: 305-360. 


\section{https://doi.org/10.1016/0304-405X(76)90026-X}

Khamis. R, Elali W, and Hamdan. A. (2015). "The Effect of Dividends and Institutional Ownership on Performance of Companies Listed on Bahrain Stock Exchange". Jordan Journal of Business Administration. 11 (4). 921 - 941.

Krivogorsky, V. (2006). "Ownership, board structure and performance in continental Europe" . The International Journal of Accounting, 41(2), 176-197. http://dx.doi.org/10.1016/j.intacc.2006.04.002

Kumar, J. (2003). "Does Ownership Structure Influence Firm Value? Evidence from India. Working Paper, Indira Gandhi Institute of Development Research, India.

Loderer, C., Martin, K., (1997)." Executive stock ownership and performance: tracking faint traces". Journal of Financial Economics 45, 223-255

McConnell, J.J., Servaes, H., (1990). "Additional evidence on equity ownership and corporate value”. Journal of Financial Economics, 27, 2, 595-612.

https://doi.org/10.1016/0304-405X(90)90069-C

Mehran, H., dan Cole R. A. (2008). “ The Effect of Changes in Ownership Structure on Performance: Evidence from the Thrift Industri”. Journal of Financial Economics 50, 291-317.

Miller MH, Rock K (1985). "Dividend policy and asymmetric information”.J. Finance., 40: 1031-1051. https://doi.org/10.1111/i.1540-6261.1985.tb02362.x

Morck, R., Nakamura, M., \& Shivdasani, A. (2000, Oct.). "Banks, Ownership Structure, and Firm Value in Japan". The Journal of Business, 73(4), 539-567. https://doi.org/10.1086/209654

Morck, R., Shleifer, A., Vishny, R.W. (1988). "Management ownership and market valuation: An empirical analysis". Journal of Financial Economics, 20, (1-2), 293-315. https://doi.org/10.1016/0304-405X(88)90048-7

Murekefu, T.M. \&Ouma, O.P. (2013). “ The relationship between dividend payout and firm performance: A study of listed companies in Kenya”. European Scientific Journal. 8(9), 199-215.

Nadia, T. (2004). "Ownership Structure, Board Characteristics, and Firm Profitability”, Master Dissertation, Hashemite University, Jordan

Priya, K.\&Nimalathasan, B. (2013)."Dividend Policy Ratios and Firm Performance: a case study of Selected Hotels \& Restaurants in Sri Lanka". Global Journal of Commerce and Management Perspective. 2 (6),16-22.

Rathinasamy, R.S., Krishnaswamy, C.R. \& Mantripragada, K.G. (2000). "Capital structure and product market interaction: an international perspective". Global Business and Finance Review, 5(2), 51-63.

Sarac, M. (2002). “ An Empirical Analysis of Corporate Ownership Structure in Turkish Manufacturing Sector”. Working Paper, Bogazici University, Istanbul. 
Al Sa'eed | The Impact of Ownership Structure and Dividends on Firm's Performance

Schooley, D. and Barney, J., D. (1994). "Using Dividend Policy and Managerial Ownership to Reduce Agency Costs". Journal of Financial Research, 17(3), 363-373. https://doi.org/10.1111/i.1475-6803.1994.tb00198.x

Severin, E. (2001). "Ownership Structure and the Performance of Firms: Evidence from France. European Journal of Economic and Social Systems". 15(2),85-107 https://doi.org/10.1051/ejess:2001117

Sher, P.J. and P.Y. Yang (2005). "The effects of innovative capabilities and R\&D clustering on firm performance: the evidence of Taiwan's semiconductor industry". Technovation, 25 (1), 33-43. https://doi.org/10.1016/S0166-4972(03)00068-3

Shleifer, A. \& Vishny, R. (1986). “ Large Shareholders and corporate control”. Journal of Political Economy. 94, 461-488. https://doi.org/10.1086/261385

Short. H and Keasey. K ( 1999).”Managerial ownership and the performance of firms: Evidence from the UK". Journal of Corporate Finance. 5(1), 79-101 https://doi.org/10.1016/S0929-1199(98)00016-9

Shu-Ching, C. and Wenching, F. (2006). "A Study on the Factors of Manufacturer Profitability: The Moderating Effect of Different Industries". Journal of American Academy of Business, Cambridge, 8(2),138- 144

Sulong, Z., and Nor, F.( 2008). "Dividends, ownership structure and board governance on firm value: empirical evidence from Malaysian listed firms". Malaysian Accounting Review, 7(2), 55-92.

Stulz. R( 1988) ." Managerial control of voting rights: Financing policies and the market for corporate control". Journal of Financial Economics. 20(1-2), 25-54

https://doi.org/10.1016/0304-405X(88)90039-6

Thomsen, S., \& Pedersen, T. (2000). "Ownership Structure and Economic Performance in the Largest European Companies”. Strategic Journal Management, 21(6), 689-705. https://doi.org/10.1002/(SICI)1097-0266(200006)21:6<689::AID-SMJ115>3.0.CO;2-Y

Uwalomwa, U., Jimoh, J\&Anijesushola, A. (2012)."Dividend policy and firm performance: A study of listed firms in Nigeria". Accounting and Management Information Systems. $11(3), 442-454$.

Wan, K. (1999) . "Do Ownership and Firm Performance Proxies Matter? An Empirical Study of the Relation of Ownership Structure and Firm". Working paper.

Wolfe, J and Sauaia, A.C. (2003). "The Tobin q as a Company Performance Indicator, Developments in Business Simulation and Experiential Learning”.30.

Wu, S. and H. Cui (2002), "Consequences of the Concentrated Ownership Structure in Mainland China". Evidence of Year 2000, working paper.

Zeckhouser R.J. \& Pound, J. (1990). "Are large shareholders effective monitors? An investigation of share ownership and corporate performance in Hubbard, R.G". (ed.), Asymmetric information, corporate finance and investment, Chicago: The University of Chicago Press. 
AABFJ | Volume 12, no. 3, 2018

Zeitun R, Tian GG. (2007). “ Capital structure and corporate performance: Evidence from Jordan”. Australasian Accounting, Business \& Finance Journal, 1(4), 40-61. 